\section{Television Demonstrations in London}

EXPERIMENTAL television programmes are being transmitted by the B.B.C. until further notice between 11 a.m. and 12 noon and 3.0-4.0 p.m. daily. A demonstration television receiver has been installed at the Science Museum, South Kensington, upon which the B.B.C. transmissions from the Alexandra Palace are received. The receiver has been lent by Messrs. A. C. Cossor, Ltd., and is of the type which is now available to the public for home reception. A special aerial has been erected on the roof of the Museum, and the receiver has been installed in one of the basement galleries where provision has been made for visitors to see the demonstrations. The Southern Railway has also provided television receivers at Waterloo Station for the use of ticketholders.

\section{Announcements}

ThE Thomas Hawksley Lecture of the Institution of Mechanical Engineers will be delivered on Novem. ber 6 by Prof. A. Fowler, who will take as his subject "The Spectroscope and the Atom".

THE council of the Illuminating Engineering Society has awarded the Gaster Memorial Premium to Mr. Ralph G. Hopkinson, for his paper on "The Photographic Representation of Street Lighting Installations", read before the joint meeting of the Illuminating Engineering Society and the Royal Photographic Society last December ; and the Silver Jubilee Commemoration Award to Mr. W. R. Stevens, for his experimental work on "Thermal Endurance of Illuminating Glassware".

The Masters Memorial Lectures of the Royal Horticultural Society will be given in the lecture room of the Socisty's New Hall in Greycoat Street, Westminster, on October 27 and November 10, at 3.30 p.m., by Dr. Redcliffe N. Salaman, on "The Potato in its Early Home and its Introduction into Europe".

Dr. Pasteur Valuery-Radot, a distinguished Paris physician and grandson of Pasteur, who is well known for his work on anaphylaxis and asthma, has been elected a member of the Paris Academy of Medicine.

Dr. Etrenne Burnet, formerly assistant director of the Pasteur Institute of Tunis and expert in the public health organization of the League of Nations, has been nominated director of the Pasteur Institute at Tunis in succession to the late Dr. Charles Nicolle.

THE Riberi prize, founded by an Italian surgeon, for the best contribution to the progress of medicine within the last five years, has recently been awarded to Dr. Francesco Pentinalli, professor of general pathology at Florence, for his work on experimental tumours and cancer. The articles submitted for the prize numbered 273 and emanated from 38 contributors from nine different countries.

TrFe Indian Science Congress, which will be held at Hyderabad on January 2-8, 1937, will consist of sections of mathematics and physics, chemistry, geology and geography, botany, zoology, anthropology, agriculture, medical and veterinary science and physiology and psychology. Further information can be obtained from Dr. H. Hyder Ali Khan, Medical College, Osmania University, Hyderabad.

Tre Central Office of the World Power Conference, 36 Kingsway, London, W.C.2, announces that it will publish on October 28 the first number of the "Statistical Year Book of the World Power Conference" (price $£ 1$ ). This volume will contain an inventory of the power resources of the world, and annual statistics, relating to 1933 and 1934 , of the production, stocks, imports, exports, and consumption of solid and liquid fuels, natural gas, water power, and electricity.

Applications are invited for the following appointments, on or before the dates mentioned:

A technical officer for experimental work with ground and aireraft radio direction-finders at the Royal Aircraft Establishment, South Farnborough. Hants-Chief Superintendent, quoting No. A. 243 (October 12).

A lecturer in mining subjects in the Municipal College, Burnley-Director of Education, Educational Office, Burnley (October 12).

A lecturer in the Department of Architecture, Building and Structural Engineering, Rutherford Technical College-Director of Education, City Education Office, Northumberland Road, Newcastleupon-Tyne, 2 (October 14).

Chemists (male) and a junior assistant chemist (male) at H.M. Factory, Irvine-Under-Secretary of State (C. 5), War Office, London, S.W.1 (October 17).

An assistant lecturer in the Aeronautics Depart. ment, Imperial College of Science and Technology, S.W.7-Secretary of the College (October 17).

An assistant biochemical engineer in Saorstat Alcohol Factories, Irish Free State-Managing Direc tor of the Factories, Department of Industry and Commerce, 14/15 St. Andrews Street, Dublin (October 17).

An assistant lecturer in engineering at the School of Mines, Treforest-Director of Education, County Hall, Cardiff (October 19).

A eivilian technical officer in the Department of Scientific Research and Experiment, AdmiraltySecretary of the Admiralty (C.E. Branch), Whitehall, S.W.1, quoting C.E. 6024/36 (October 24).

A library assistant at the Research Department, Institution of Automobile Engineers, Great West Road, Brentford, Middlesex.

Engineers for the Public Works Department (temporary staff) of the Government of Nigeria-Crown Agents for the Colonies, 4 Millbank, London, S.W.1, quoting $\mathrm{M} / 4500$.

A lecture assistant and laboratory steward for the Chemistry Department, Sir John Cass Technical Institute, Jewry Street, London, E.C.3-ThePrincipal.

A lecturer in theory of structures and structural design, and a lecturer in electrical engineering at the Medway Technical College, Gardiner Street, Gilling. ham-Mr. C. Colles. 